\title{
The Myth Strength In Indonesian Novels As The Representation Of Religious and Sacredness Literacy Of Indonesian Society
}

\author{
Purwati Anggraini ${ }^{1}$, Kisyani Laksono ${ }^{2}$, Mintowati ${ }^{3}$ \\ Universitas Negeri Surabaya and Universitas Muhammadiyah Malang \\ Jalan Ketintang no.30, Ketintang, Gayungan, Surabaya, Jawa Timur 60231, Indonesia, Jalan \\ Raya Tlogomas 246 Malang, Jawa Timur 65144, Indonesia ${ }^{1,3}$ \\ Universitas Negeri Surabaya'Jalan Ketintang no.30, Ketintang, Gayungan, Surabaya, Jawa \\ Timur 60231, Indonesia ${ }^{2}$ \\ \{poer1979ang@gmail.com¹
}

\begin{abstract}
Myth is one of the local wisdom of a particular region and has become a valuable cultural heritage. Myth in Indonesia serves life guidance and is taken into other aspects, such as novels writing. Myth is the strength and strong representation of religious literation and sacredness of the Indonesian society. This study aims to describe the myth's strength in Indonesian novels to represent Indonesian society's religious literation and sacredness. The study uses a qualitative method in applying literacy theory. The study's object is a novel by Pandu Hamzah entitled Sebuah Wilayah yang Tidak Ada di Google Earth and Sokola Rimba by Butet Manurung. The study comprises several steps: setting research objectives, collecting data by reading the object of research, entering it in a data filter table, and coding. Data analysis was carried out by double checking the collected data, describing, interpreting, and finally drawing conclusions. The study results show that the community believed in the myths of spirits, the myths of giving offerings at salvation ceremonies, and the myths of living beings that provide benefits. The two novels' myths can serve the guidance function for the society to act wisely towards the environment. Society has more consideration in conducting a particular action as the impact of the myths is considered significant. The harmony between people and nature can prevail through the myth practice as a belief in society. Myths for Indonesian people are local wisdom that serves the fundamental principles in maintaining the natural balance, both the macrocosm and microcosm.
\end{abstract}

Keywords: myth; novel; religious literacy; sacredness; natural balance

\section{Introduction}


Most Indonesians believe in myths. Therefore, myths are interesting to discuss, as Indonesian consider myths as a part of taking action. They pass on myths to the next generation in various ways, such as becoming media in educating their children. Myth is often considered related to superstition; nevertheless, myths contain values that can lead a person to do good deeds for him/ herself, other people, other living beings; it even can increase one's faith (Endraswara, 2010).

Myth is a part of the supernatural world. The appreciation of the supernatural is inseparable from Indonesian life, especially Javanese (Suseno, 1999). Nevertheless, not only Javanese but also almost all parts of Indonesia believe in superstition and the supernatural world, especially myths. Therefore, this phenomenon is taken to novels by authors; one of them is Pramoedya Ananta Toer. Taum (2013) explained that a novel entitled Arus Balik by Pramoedya Ananta Toer offers an interesting narration of marine myths. The Indonesian marine myths reflect the nation's glory that can break the shallowness of mind and thoughts. Therefore, the insight must be improved to maintain the nation's greatness in Indonesia. The myths taken into account in the novel prove that it is not merely superstition, but more than that, it has values as the principles in conducting deeds and behaviors. Myths represent religious literacy and the sacredness of Indonesian society that function as a balancing media between the microcosm and macrocosm.

Culturally, the Indonesian literacy initially was ethnical literacy written in the Indonesian language. As a literary form derived from ethnic culture, it always relates to various aspects within its scope, especially its source closely related to the author's ethnic background that has brought him/her become famous (Sudikan, 2013). Therefore, this study will discuss two Indonesian novels related to myths as a principle for society's interaction with nature. The novels taken for this study are Sokola Rimba by Butet Manurung, and Sebuah Wilayah yang Tidak Ada dalam Google Earth by Pandu Hamzah. The two novel portrait the people of Ceremai Mountain and rural Jambi who still strongly believe in myths. To maintain myths as local wisdom can provide well-being to society and guide them to keep natural sustainability.

The themes are interesting to be highlighted, not only as the complementary of the story but also as a medium to deliver the author's message on the importance of myths in daily life, especially in treating the environment wisely. As explained by Sukatman (2009), myths are one of the beliefs in Indonesian society functioning as (a) talking ideas to stay awake during late hours, (b) teaching preservation, (c) thought control, (d) humor materials, and (e) disarray material to disturb society.

Myths, as a part of the spoken tradition of the Indonesian society, is still relevant to the present situation because it may become the reference for the human to appreciate their lives to the universe. Myth consists of cultural facts, such as genealogy, cosmology, cosmogony, ethics, morality, etc (Dwija, 2013). The fact means that in viewing myths, people act microcosmic and at the same time become a member of the macrocosmic. In the relationship, the microcosmic is wider than the macrocosmic as the universe is within the human. Humans have a heart and mind that can house the universe and even God within their souls (Wahyudi, 2014).

Therefore, in religious life, humans are closely attached to religious rituals. In the rituals, society uses a particular language believed to have magical power. The power is strongly believed to bring balance to nature, which eventually creates well beings in society. The well beings in this situation are related to the material and the peaceful being in the soul; the sustainable nature will benefit human beings. The situation is in line with Watt and Sarah (2008), saying that religious ritual language has a significant effect on society. 


\section{Method}

This study is in the form of a comparative description with an ecological approach to portray myths in society as a representation of religious literacy and sacredness. This study procedure applied the one from Jabrohim (2003) as follow:

1) To establish the subject matter.

The writer established the subject matter of myths as a representation of religious literacy and the sacredness of Indonesian society in novels entitled Sokola Rimba by Butet Manurung and Sebuah Wilayah yang Tidak Ada dalam Google Earth by Pandu Hamzah.

2) To formulate and define the problem of the study.

The writer's comparative descriptive method aims to achieve the myth concept as representing religious literacy and sacredness to help society maintain the natural balance, both the microcosmic and macrocosmic.

3) To conduct literary study.

The writer used the literary study to track the theories and results of the study on the myths and religious literacy and the sacredness of Indonesian society.

4) To collect data.

This study's objects are novels entitled Sebuah Wilayah yang Tidak Adal

dalam Google Earth by Pandu Hamzah and Sokola Rimba by Butet

Manurung. These two novels are taken as the study's object because the novels contain myth issues believed and held on to by society to represent local wisdom and religious literacy and sacredness. The data was collected by reading the object of study, entering the data in the data filter table that had been adjusted to the research indicators, and coding.

5) To process data.

After data collection is completed, it continued with data processing. The writer made data indicators and corpus according to the problem of the study that has been formulated. Data analysis is done by reviewing the data that has been collected, reducing data that is not in accordance with the indicators, describing the data, and interpreting the data. Through this process, the writer achieved myth concepts as the representation of religious literacy and society's sacredness. Finally, the writer concluded an attempt to formulate recommendations based on the appointed purpose of the study.

\section{Result Of The Study}

In the two novels that are the object of this research, one of the myths in them is the people's belief in spirits. The spirits described in the novel Sebuah Wilayah yang Tidak Ada Dalam Google Earth are forest guardian demons. This creature has several forms related to its role as a guardian of the forest.

Myths about the supernatural, in this case, the belief in forest-guarding creatures, is a warning symbol for humans. Humans live side by side with nature. What happens in nature is believed to be a form of representation of human behavior. Humans should maintain the balance of nature, maintain good relations with their social environment, and immediately 
repent or apologize when they make mistakes. When this myth is held tightly, then humans will be able to achieve peace and prosperity.

Apart from myths, the Indonesian people often hold festivals to be grateful for God's favors and an effort to ward off misfortune. Usually, during this celebration, the community also provides well-prepared offerings. These offerings are believed by the community to eliminate fears of natural disasters. The community's ancestors had already given these offerings. In addition to a more positive celebration ceremony, people also recognize rituals to gain the gendam. This type is one of the black magic, which is believed to make other people obey the owner of the magic. This knowledge usually aims to protect oneself from danger or greedy parties or those who commit violations.

In the novel of Sokola Rimba, the intimate relationship of the Rimba people with nature aims to maintain their balance and harmony with nature, which is manifested in many ways. One of them is by tricking the queen bees during honey harvesting to avoid getting stung. The Orang Rimba believe that the bees will give much honey when they treat the queen bee well. This trick is manifested by chanting a spell. This mantra is believed to be a magical sentence and can completely repel the Orang Rimba's misfortune at work. The Orang Rimba also believes that the prey in the forest is a provision given by God, so they accept it. If they reject the game, they believe God will be angry and will not provide more sustenance.

The Orang Rimba learned about the myths from their parents and ancestors. As children, they are taught skills, especially skills related to creating things to fulfill their daily needs and taking food from nature for their survival. All the skills mastered by the Orang Rimba do not destroy the balance of nature.

\section{Discussion}

The natural environment and the social environment are two interconnected environments. Humans in the social environment are actors and recipients of positive impacts and negative impacts due to ecosystem processes in the natural environment (Sudikan, 2016). Humans should immediately correct their mistakes whenever they make any, both to people and other living creatures. Correcting these mistakes is the ultimate goal of belief in myth as representing religious literacy and sacredness. As used in human life, religious literacy and sacredness are a form of continuously used experiences in everyday life to make meaning of life and as a means of resilience and survival (Ivanova, 2014).

Religious literacy and sacredness can be interpreted as ritual practices, often institutionalized (in this case passed down from generation to generation as local wisdom), reflecting a set of beliefs about the sacred dimensions of reality (Bahl, 2019). This religious and sacred literacy is part of the culture, reflecting that people who are literate in religious and sacred literacy also mean cultural literacy (Chew, 2013).

In this case, it seems that myths about the supernatural, belief in forest guardian spirits, and myths about other creatures that live around humans, are one of the authors' strategies to describe myths that function to preserve the natural environment. Nature will help humans if humans do good deeds to nature.

This myth is a step taken by the community to ask God for protection so that the natural environment around it, the natural environment in which people interact with others, and other inhabitants of nature will continue to be protected from damage. This activity shows a close relationship between humans, the natural environment, and the social environment 
(Anggraini, 2018). The relationship between humans and nature must be maintained in order to create harmony. According to Tjahjono's opinion (in Endraswara, 2016), the harmony of nature with humans will create a calm atmosphere. Humans' efforts to maintain the balance of nature are simultaneously an intelligent reading by humans of the signs given by nature (Elster, 2003).

\section{Conclusion}

The myth in Ciremai Mountain's society in the novel Sebuah Wilayah yang Tidak Ada Dalam Google Earth by Pandu Hamzah and Sokola Rimba by Butet Manurung is a medium for maintaining the harmonization of human life as a microcosm and as part of a macrocosm. At the same time, this myth represents religious literacy and the sacredness of society, which is depicted in the two novels. The religious and sacred literacy in the novel shows people's intelligence in interacting, both with others, other living things, and with the supernatural world. With this literacy, humans at the same time get benefits in life, both economically, socially and culturally. This literacy is what people believe can bring happiness, both physically and emotionally.

\section{References}

[1] Anggraini, Purwati. "Mitos sebagai Upaya Pelestarian Lingkungan (Sebuah Kajian Kritik Lingkungan dalam Novel Sebuah Wilayah yang Tidak Ada dalam Google Earth Karya Pandu Hamzah)", Makalah, disampaikan pada seminar nasional dengan tema Peran Bahasa dan Sastra dalam menghasilkan Guru Profesional, Kreatif, dan Inspiratif di Era Globalisasi, tanggal 5-6 Mei 2018 di Universitas Muhammadiyah Malang. http://researchreport.umm.ac.id/index.php/SENASBASA/article/view/2635

[2] Bahl, E. K. (2019). Religion, Remediated: Engaging Religious Literacies with the DALN. The Archive as Classroom.

[3] Chew, P. G. L. (2013). The Sacred and The Secular: A Case Study of Weekend and Weekday Literacies.

[4] Dwija, I Nengah. (2013). Mitos I Ratu Ayu Mas Manembah: Pendekatan Theo Antropologi. Dalam Suwardi Endraswara (ed). Folklor Nusantara: Hakikat, Bentuk, dan Fungsi (hlm 242-262). Yogyakarta: Ombak

[5] Elster, C. A. (2003). Authority, Performance, and Interpretation in Religious Reading: Critical Issues of Intercultural Communication and Multiple Literacies. Journal of Literacy Research, 35(1), 663-692.

[6] Endraswara, Suwardi. (2010). Folklor Jawa: Bentuk, Macam, dan Nilainya. Jakarta:Penaku.

[7] Endraswara, Suwardi. 2016. Ekologi Sastra (Konsep, Langkah, dan Penerapan). Yogyakarta: CAPS (Center for Academic Publishing Service).

[8] Ivanova, C. (2014). Memories as Sacred Artifacts and Remembering as A Sacred Literacy. Humanities and Social Sciences Review, 3(5), 275-282.

[9] Jabrohim (ed). 2003. Metodologi Penelitian Sastra. Yogyakarta: Hanindita Graha Widya. 
[10] Sudikan, Setya Yuwana. (2013). Kearifan Budaya Lokal. Sidoarjo: Damar Ilmu.

[11] Sudikan, Setya Yuwana. (2016). Ekologi Sastra. Lamongan: CV Pustaka Ilalang Grup.

[12] Sukatman. (2009). Butir-Butir Tradisi Lisan Indonesia. Yogyakarta: Laksbang Pressindo

[13] Suseno, Franz Magnis. (1999). Etika Jawa. Jakarta: Gramedia Pustaka Utama

[14] Taum, Yoseph Yapi. (2013). Berbagai Mitos Tentang Laut: Mengungkap Konsep Bahari Bangsa Indonesia. Dalam Suwardi Endraswara dkk (eds), Folklor dan Folklife dalam Kehidupan Dunia Modern: Kesatuan dan Keberagaman (hlm. 183-191). Yogyakarta: Ombak

[15] Wahyudi, Agus. (2014). Pesona Kearifan Lokal. Yogyakarta: Dipta

[16] Watt, Jonathan M dan Sarah L. Fairfield. (2008). Religious and Sacred Literacies. Dalam Bernard Spolsky dan Francis M. Hult (eds), The Handbook of Educational Linguistics (hlm 355-366). United Kingdom: Blackwell Publishing 